\title{
Clinical Study \\ Thyroid Peroxidase Gene Mutation in Patients with Congenital Hypothyroidism in Isfahan, Iran
}

\author{
Mahin Hashemipour, ${ }^{1}$ Fahimeh Soheilipour, ${ }^{1}$ Sakineh Karimizare, ${ }^{2}$ \\ Hossein Khanahmad, ${ }^{2}$ Morteza Karimipour, ${ }^{2}$ Sepideh Aminzadeh, ${ }^{2}$ \\ Leila Kokabee, ${ }^{2}$ Massoud Amini, ${ }^{3}$ Silva Hovsepian, ${ }^{1}$ and Rezvaneh Hadian ${ }^{3}$ \\ ${ }^{1}$ Isfahan Endocrine and Metabolism Research Center, Child Growth and Development Research Center, \\ Isfahan University of Medical Sciences, Isfahan, Iran \\ ${ }^{2}$ Molecular Medicine Department, Pasteur Institute of Iran, Tehran, Iran \\ ${ }^{3}$ Isfahan Endocrine and Metabolism Research Center, Isfahan University of Medical Sciences, Isfahan, Iran
}

Correspondence should be addressed to Fahimeh Soheilipour, fsoheilipour@yahoo.com

Received 12 January 2012; Revised 6 May 2012; Accepted 20 May 2012

Academic Editor: Stuart Tobet

Copyright (C) 2012 Mahin Hashemipour et al. This is an open access article distributed under the Creative Commons Attribution License, which permits unrestricted use, distribution, and reproduction in any medium, provided the original work is properly cited.

\begin{abstract}
Background. Thyroid peroxidase gene (TPO) mutations are one of the most common causes of thyroid dyshormonogenesis in patients with congenital hypothyroidism $(\mathrm{CH})$. In this study, the prevalence of TPO gene mutations in patients with thyroid dyshormonogenesis in Isfahan was investigated. Methods. In this cross-sectional study, genomic DNA of 41 patients with permanent $\mathrm{CH}$ due to thyroid dyshormonogenesis was extracted using the salting out method. The 17 exonic regions of the TPO gene were amplified. SSCP technique was performed for scanning of the exonic regions of the TPO gene, except exon 8. DNA sequencing was performed for those with different migration patterns in SSCP by chain termination method. Exon 8 was sequenced directly in all patients. In 4 patients, all fragments were also sequenced. Results. One missense mutation c.2669G > A (NM_000547.5) at exon 15 (14th coding exon) in one patient in homozygous form and seven different single nucleotide polymorphisms (SNPs) in exons 1, 7, 8, 11, and 15 of TPO gene. Conclusion. The TPO gene mutations among CH patients with dyshormonogenesis in Isfahan were less frequent in comparison with other similar studies. It may be due to the presence of other unknown gene mutations which could not be detected by SSCP and sequencing methods.
\end{abstract}

\section{Introduction}

Congenital hypothyroidism $(\mathrm{CH})$ is the most common congenital endocrine disorder in childhood which is associated with irreversible neurological problems and poor growth in untreated individuals. In Europe and North America, 1 in 3,000 to 4,000 newborns is affected by this disease $[1,2]$.

In the majority of patients, $\mathrm{CH}$ is sporadic and caused by an abnormal development of the thyroid gland (thyroid dysgenesis). Hereditary inborn errors in the enzymatic cascade of thyroid hormone synthesis are accounted in $20 \%$ of all cases which is defined as thyroid dyshormonogenesis. This disorder typically transmitted in an autosomal recessive manner [3].

Of the several genetic defects responsible for thyroid dyshormonogenesis, mutations in thyroid peroxidase (TPO) gene are the most prevalent causes of inherited defects in $\mathrm{CH}$ [4]. The TPO gene is located on chromosome 2p25, containing 17 exons encoding a protein of 933 amino acids. Thyroid peroxidase protein is a membrane-bound enzyme which involves in the biosynthesis of thyroid hormones [5]. TPO mutations have been described in various ethnic populations. So far more than 60 inactivating mutations associated with TPO gene have been identified including missense and nonsense mutations, splicing errors, deletions, and insertions of nucleotides. Prevalent mutations are in exons $8,9,10$, and 11 (catalytic site) [6-24].

Since 2002, the neonatal screening program for $\mathrm{CH}$ has been initiated in Isfahan, Iran. The incidence of $\mathrm{CH}$ in this population was estimated to be $1: 357$ newborns which is about 10 times higher than reports from North America and Europe [25]. 
TABle 1: Primers used for PCR Amplification of thyroid peroxidase gene.

\begin{tabular}{|c|c|c|c|c|c|c|}
\hline \multirow{2}{*}{ Exon } & \multicolumn{2}{|r|}{ Forward Primers } & \multicolumn{2}{|r|}{ Reverse Primers } & \multirow{2}{*}{$\begin{array}{l}\text { Fragment } \\
\text { size (bp) }\end{array}$} & \multirow{2}{*}{$\begin{array}{l}\text { Annealing } \\
\text { temperature }\end{array}$} \\
\hline & $\begin{array}{c}\text { Position of } \\
5^{\prime} \text { end }\end{array}$ & Nucleotide sequence $\left(5^{\prime} \rightarrow 3^{\prime}\right)$ & $\begin{array}{c}\text { Position of } \\
5^{\prime} \text { end }\end{array}$ & Nucleotide sequence $\left(5^{\prime} \rightarrow 3^{\prime}\right)$ & & \\
\hline (1) & -70 & GACTTCCTAGCATCTTGACG & +67 & CACTTTACAAGTTCCAATGATG & 220 & $58^{\circ} \mathrm{C}$ \\
\hline (2) & -74 & AGACAAGGACACAGCGGTTC & +95 & CATGGCCTTGTCAGTGCTTG & 225 & $60^{\circ} \mathrm{C}$ \\
\hline (3) & -67 & AAGCAACACTGTCAGTGAATC & +123 & TTAACAATGGCAAGCTTCAG & 275 & $60^{\circ} \mathrm{C}$ \\
\hline$(4)$ & -60 & TT AAGTACCAAAGATACCATAGAC & +65 & CACAAAGTCAAGGTGTCCTC & 295 & $60^{\circ} \mathrm{C}$ \\
\hline (5) & -101 & CAAATTCAGATGCTGGAGTCAC & +73 & TCCTTCATGATGGCATCTAGTC & 308 & $61^{\circ} \mathrm{C}$ \\
\hline (6) & -86 & CTGAGAATGGTGTCTTATATCTG & +52 & AGCATCACAGGACCCAATC & 313 & $61^{\circ} \mathrm{C}$ \\
\hline (7) & -61 & GTCATCTTTCTGCTACCACG & +60 & TTGACGTTTTAAATAGCACTTAG & 327 & $55^{\circ} \mathrm{C}$ \\
\hline (8) & -60 & AGAGTCTTACAA AGG GTG CAC & +163 & AAG TAC CTG GGA GAG AGA AGC & 678 & $60^{\circ} \mathrm{C}$ \\
\hline (9) & -29 & TCA CTGAGATGCTTTTCCTAT C & +45 & AAGAGTTCATGGGGACCAG & 327 & $60^{\circ} \mathrm{C}$ \\
\hline (10) & -55 & GTTTCTCTAGAACTGAGCCAAG & +79 & AGTCTCTCTAGCAGCAGGTTG & 306 & $61^{\circ} \mathrm{C}$ \\
\hline (11) & -51 & AACAAAAGTTCAGTTCTGTGAGAG & +44 & TGTGCAGAACGTGAAGGAAG & 330 & $61^{\circ} \mathrm{C}$ \\
\hline (12) & -42 & CTC CAT GCA CTG TGA CCT TAC & +57 & CTTTGTTTGATGAGATGCACG & 308 & $61^{\circ} \mathrm{C}$ \\
\hline (13) & -46 & CTTTTCTCGTAGTTTGACTACATG & +54 & CTTATATCGGAAACATTCAGATG & 271 & $60^{\circ} \mathrm{C}$ \\
\hline (14) & -69 & AGAGAAGCACCTCCCAGAAC & +69 & TACAAAAACTCGCAAATGGAC & 270 & $61^{\circ} \mathrm{C}$ \\
\hline (15) & -75 & CAGACTCAGGCAGGACAACC & +69 & ATTGCAGCCATGTCCAGAG & 244 & $61^{\circ} \mathrm{C}$ \\
\hline$(16)$ & -61 & CTACCCTCCACAGTCACGGT & +59 & CCAGATCCTGTCCAACCACT & 250 & $62^{\circ} \mathrm{C}$ \\
\hline$(17)$ & -108 & TGTGAAAAGAGCTCCTGTC & +49 & GTGATTTTGGGAACATGAAG & 211 & $62^{\circ} \mathrm{C}$ \\
\hline
\end{tabular}

This difference is more likely due to iodine deficiency which is the main cause of transient $\mathrm{CH}$ [26]. According to the recent studies, Isfahan population has become iodide sufficient [27]. But the rate of permanent $\mathrm{CH}$ in Isfahan is higher than the comparable worldwide rates [28]. Further investigation has shown that thyroid dyshormonogenesis is the most common aetiology of $\mathrm{CH}$ in this population $[29,30]$.

Considering the high prevalence of thyroid dyshormonogenesis in Isfahan and the role of TPO gene mutation in the etiology of this type of $\mathrm{CH}$, in the present study, the frequency of TPO gene defects in patients with thyroid dyshormonogenesis was detected.

\section{Material and Methods}

2.1. Patients. In this cross-sectional study, 41 dyshormonogenetic $\mathrm{CH}$ patients, diagnosed and followed up during $\mathrm{CH}$ screening program in Isfahan Endocrine and Metabolism Research Center, were enrolled. The Medical Ethics Committee of the Isfahan Endocrine and Metabolism Research Center approved the study protocol, and parents of all selected $\mathrm{CH}$ patients gave their written consent.

According to $\mathrm{CH}$ screening guideline, neonates with screening TSH level of $>10 \mathrm{mIU} / \mathrm{L}$ at 3-7 days of life recalled. The newborns with abnormal screening results were reexamined on 7 th-15th days of birth. Neonates were considered as $\mathrm{CH}$ when having $\mathrm{TSH}>10 \mathrm{mIU} / \mathrm{L}$ and $\mathrm{T}_{4}<6.5 \mathrm{mg} / \mathrm{dL}$ in second measurements. Thyroid hormone replacement therapy was started in the form of $\mathrm{L}_{-} \mathrm{T}_{4}$ (levothyroxine) within the first 2 weeks of life. Permanent cases were determined at 3 years old by measuring TSH and T4 concentration 4 weeks after withdrawal of $\mathrm{L}_{-} \mathrm{T}_{4}$ levothyroxine therapy. Patients with elevated TSH levels (TSH > $10 \mathrm{mIU} / \mathrm{L}$ ) and decreased $\mathrm{T}_{4}$ levels $\left(\mathrm{T}_{4}<6.5 \mu \mathrm{g} / \mathrm{dL}\right)$ at this time were considered as permanent $\mathrm{CH}$. The etiology of $\mathrm{CH}$ was determined by thyroid scan and/or ultrasound before treatment in neonatal period or at age of 3 years old after confirming the permanency of $\mathrm{CH}$. Patients with thyroid gland of normal size according to radiologic findings (i.e., those without thyroid agenesis, hypoplasis, hemiagenesis, or ectopia) were considered to have dyshormonogenesis.

Peripheral blood samples were obtained from selected patients and transferred to Molecular Medicine Department of Pasteur Institute of Iran for molecular analysis and determining the TPO gene mutations.

Serum $\mathrm{T}_{4}$ and $\mathrm{TSH}$ were measured by radioimmunoassay (RIA) and immunoradiometric assay (IRMA) methods, respectively.

2.2. DNA Isolation and Amplification. Genomic DNA was extracted from white peripheral blood cells using the salting out method [31].

Primers were specially designed using the computer program (Gene Runner), for all of the 17 exons and exon-intron boundaries of TPO gene. Their oligonucleotide sequences and the position of their $5^{\prime}$ coding sequence ends are listed in Table 1.

The 17 exonic regions of the TPO gene, including the splicing regions, were amplified by polymerase chain reaction (PCR). The PCR reaction mixture contained $10 \mathrm{pmol}$ of each forward and reverse primers, $500 \mathrm{ng}$ genomic DNA, $2 \mathrm{mM} \mathrm{MgCl} 2,200 \mu \mathrm{M}$ of each dNTP (Cinnagene, Iran), $2.5 \mu \mathrm{L} 10 \mathrm{x}$ PCR buffer, $0.5 \mathrm{U}$ Taq DNA polymerase (Cinnagene, Iran) at a final volume of $25 \mu \mathrm{L}$. For amplification of exon $8,1 \mu \mathrm{L}$ dimethyl sulfoxide (DMSO) was added. 
The PCR reactions were performed in a thermal cycler machine (Eppendorf, Germany) with an initial denaturation of $10 \mathrm{~min}$ at $95^{\circ} \mathrm{C}$, followed by 30 cycles of amplification consisting of denaturation at $95^{\circ} \mathrm{C}$ for 50 second, annealing at $55-62^{\circ} \mathrm{C}$ (depend on suitable annealing temperature for each primer) for 40 seconds and extension at $72^{\circ} \mathrm{C}$ for 30 60 seconds (depending on PCR products length) and with a final extension at $72^{\circ} \mathrm{C}$ for $5 \mathrm{~min}$.

\subsection{Single Strand Conformation Polymorphism (SSCP) Anal-} $y$ sis and DNA Sequencing. All amplified PCR products except exon 8 of TPO gene were screened by single-strand conformational polymorphism analysis (SSCP) from 41 selected patients and normal controls. The gel matrix for SSCP contained $8 \%$ polyacrylamide gel $(29: 1$ or $39: 1)$ (Qiagen, Germany) with $3 \%$ glycerol. For SSCP, $5 \mu \mathrm{L}$ of PCR products were first mixed with a $7 \mu \mathrm{L}$ SSCP loading buffer (xylene cyanol $0 \cdot 05 \%$, bromophenol blue $0 \cdot 05 \%$, formamide $95 \%$ ), the mixture was incubated at $95^{\circ} \mathrm{C}$ for 10 minutes and then was transferred quickly in to ice bath. Samples were electrophoresed for 10-16 hours at a constant temperature $\left(4^{\circ} \mathrm{C}\right)$. Gels were stained by standard silver staining method to visualizing DNA. Fragments presenting different migration pattern in comparison with normal controls were directly sequenced for nucleotide change identification.

Exon 8 of TPO gene was sequenced directly in all patients. In 4 patients, all fragments were sequenced besides SSCP analysis. For sequencing, PCR fragments were purified by DNA Gel Extraction Kit (Qiagen, Germany). Sequencing analysis was done based on chain termination method, using forward and reverse primers in Table 1.

2.4. Data Analysis. Sequences were analyzed, using chromas program and compared with the normal TPO gene sequence (Gen Bank Accession number: DQ011222) by BLAST online software (http://www.ncbi.nlm.nih.gov/blast/). Nucleotide changes were compared with mutation database of TPO gene (http://www.hgmd.cf.ac.uk/).

\section{Results}

In this study, 41 patients ( 15 male and 18 female) with dyshormonogenetic congenital hypothyroidism were evaluated for TPO gene mutation. Mean age of studied population was $44.6 \pm 5.7$ months. Mean of screening TSH and $\mathrm{T}_{4}$ level in studied population was $46.2 \pm 37.1(\mathrm{mIU} / \mathrm{L})$ and $6.0 \pm 2.8(\mu \mathrm{g} / \mathrm{dL})$, respectively. $63 \%(26 / 41)$ of patients had parental consanguinity (18 of them had first-degree parental consanguinity). None of them had goiter during clinical examination.

TPO gene mutation was detected only in one patient. The mutation was located in exon 15 (14th coding exon) of TPO gene at nucleotide position c.2669G > A (NM_000547.5) (Figure 1). This mutation results in a glycine to arginine substitution at amino acid position 860 p.Gly860Arg in homozygous form. This mutation has been described previously in the database [17].

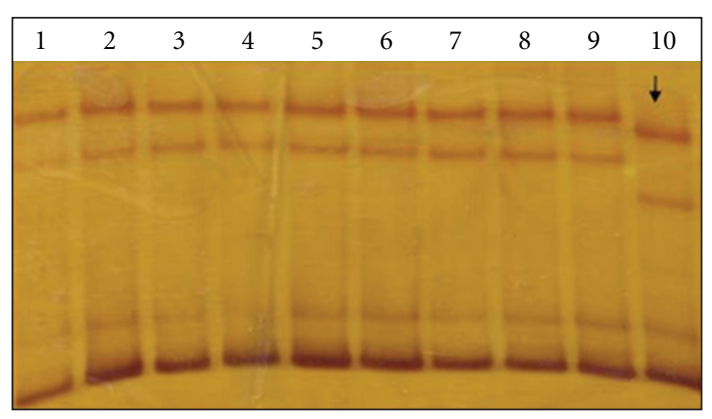

(a)

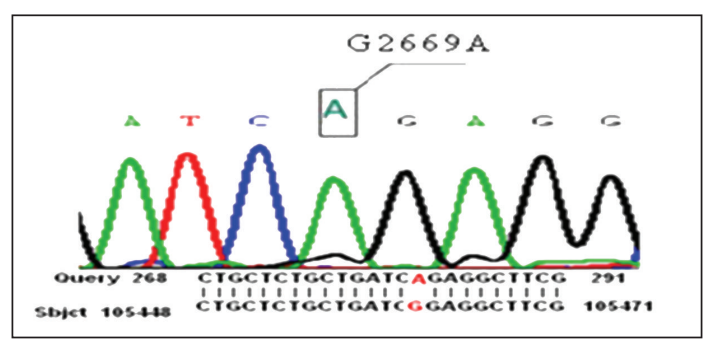

(b)

FIGURE 1: (a) SSCP analysis of exon 15 fragments of thyroid peroxidase (TPO) gene in nine patients with thyroid dyshormonogenesis of Isfahan, Iran. Line 1: normal control. Line 2-8: patients that did not have aberrant shift and mutation in exon 15. Line 9: the patient with homozygous G2669A mutation in exon 15. (b) Sequencing analysis result of patient with homozygous G2669A mutation in exon 15.

For further analysis, SSCP and DNA sequencing of this exon were performed for the family. The data showed that the mutation is present in heterozygous form in the parents (Figure 2). The parents of the proband have had first cousin marriage.

The affected patient was characterized by SSCP as having aberrant shift in exon 15 (14th coding exon) that was not detected in normal subject and other patients and was found homozygous for this mutation in sequencing analysis result (Figure 1) SSCP of exon 15 showed altered migratory patterns in both parents of affected patient, and sequence analysis in them revealed that they carried this mutation (Figure 2).

In addition, six known single nucleotide polymorphisms were detected in this cohort by SSCP and sequencing analysis. Two of them were located in the promoter region and in exon 1 (A-35G, G11A) and others in the reading frame c. $859 \mathrm{G}>\mathrm{T}$, c. $1207 \mathrm{G}>\mathrm{T}$, c. $1283 \mathrm{G}>\mathrm{C}$, c. $2088 \mathrm{C}>\mathrm{T}$ ).

Full sequencing of TPO gene in four patients detected no mutation, and SSCP results and sequencing analysis results were similar in these patients.

\section{Discussion}

TPO gene mutations are the main causes of thyroid dyshormonogenesis [6-24]. In the present study, the whole gene scanning of TPO gene by SSCP and sequencing was performed in 41 patients with permanent congenital 


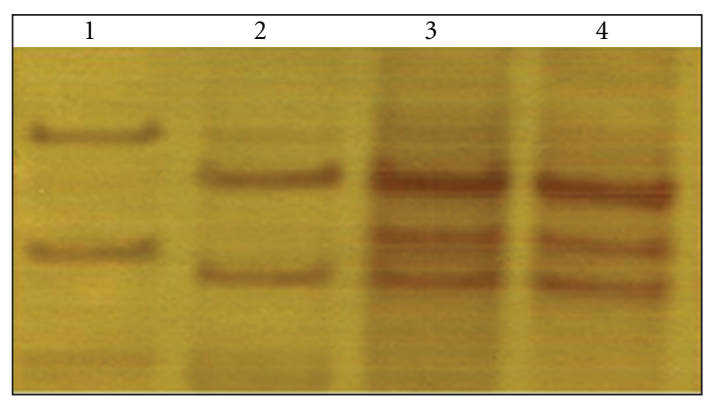

(a)

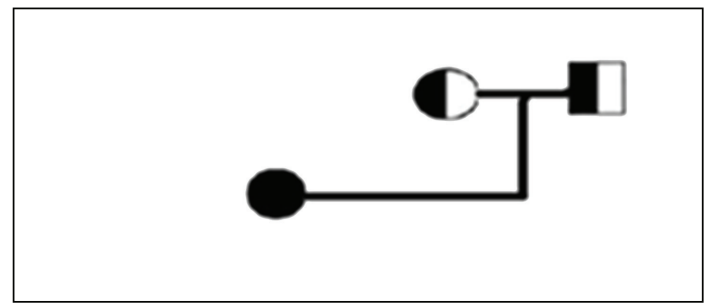

(b)

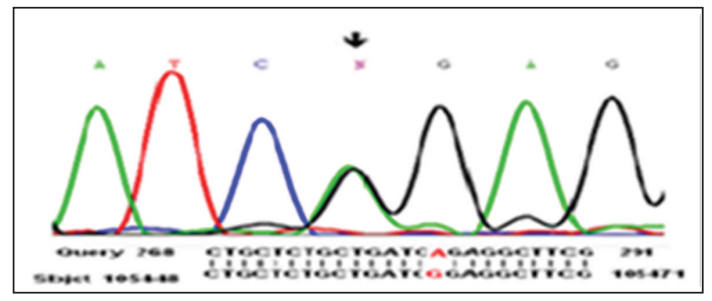

(c)

Figure 2: (a) SSCP analysis of exon 15 in affected family. Line1: Normal control, Line2: The patient that has homozygous G2669A mutation in exon 15, Line3: The affected s' mother, Line4: The affected s' father. (b) Pedigree of the affected family is aligned with the SSCP analysis. (c) Sequencing analysis result of affected s' mother and father.

hypothyroidism due to dyshormonogenesis. Only one mutation was detected in this group of patients. The reported mutation in this study c.2669G > A (NM_000547.5) is located in exon 15 of TPO gene and results in the hydrophobic glycin $(G)$ to the positively charged arginine amino acid substitution in the TPO transmembrane region. This change is effected on insertion of the TPO enzyme into the plasma membrane of thyroid follicular cells, and results decrease protein activity in the patient [17]. Both parents were heterozygous for this change so the mutation transmits as autosomal recessive traits in the affected family. Seven different single nucleotide polymorphisms (SNPs) in exons $1,7,8,11$, and 15 of the TPO gene were detected too.

As mentioned, different mutations of TPO gene have been reported previously, commonly in exons 8, 9, and 10 . The mutation of c.2669G > A (NM_000547.5) has been reported by Avbelj et al. in Slovakia, and thereafter it was not reported in other studies [17]. Mutation of exon 15 has been reported by Neves et al. in Brazil, but it was c.2630T > C mutation [32].
The patient with mentioned mutation in Slovenia had nodular goiter according to the sonographic findings at the age of 16 years [17]. In this study, the patients had not goiter according to both radiologic and clinical findings at the age of 3 years. Though it may be due to early initiation of treatment, it needs further studies in this field.

In our study, the frequency of TPO gene mutations was lower than Slovene and Portuguese population studies that had similar inclusion criteria, without doing perchlorate discharge test $[17,19]$.

In a population-based study in Japan, Narumi et al. have analyzed the prevalence of TPO gene mutation in fourteen $\mathrm{CH}$ patients with dyshormonogenesis and detected two biallelic mutations among them [33].

In this study, total iodine organification defect (TIOD) or partial iodine organification defect (PIOD) as defined by the perchlorate discharge test was not determined in studied patients. Some studies have reported that homozygous and compound heterozygous TPO gene mutations are more frequently seen among dyshormonogenic $\mathrm{CH}$ patients with TIOD $[32,34]$. It is suggested that low frequency of TPO gene mutations in our studied population may be due to the fact that most of them were dyshormonogenic $\mathrm{CH}$ patients with PIOD, which should be investigated in future studies.

In our study, number of patients and determination of permanent $\mathrm{CH}$ were similar to previous studies, so low sample size or transient disease cannot be the cause of low frequency of TPO gene mutations.

It is possible that mutations in intronic sequences or in the promoter region and unexamined regulatory regions of TPO gene are the cases of thyroid dyshormonogenesis in these patients. In addition, other genetic disorders may be more effective than TPO mutations in $\mathrm{CH}$ patients with dyshormonogenesis including the sodium symporter (NIS) gene, the pendrin gene (PDS), the thyroid oxidase gene 2 (THOX2 or DUOX2), and thyroglobulin gene [35].

The technique used in this study, SSCP, is a cheap, simple, and suitable method with a good sensitivity. It has 70-90\% sensitivity for the detection of single base substitutions [36]. In addition, small deletions and insertions in the genome could be identified by this method [37]. High prevalence of previously reported point mutations in TPO gene and high application of SSCP in detection of this type of mutations with another benefits of this method that is mentioned are reasons to choose SSCP for this study. Approximately $90 \%$ of the potential base exchanges are detectable by SSCP under optimal conditions [38]. In present study, detection of several single nucleotide polymorphisms in different regions of TPO gene with SSCP and similarly results of direct sequence analysis in four patients showed high sensitivity of SSCP in our study. But SSCP like another mutations screening methods may have percentage of error rate. The limitations of SSCP method are high depen. So in the present study, there is probability of existing mutations that are unidentified with SSCP.

We know, long homozygous deletions in the gene are caused of autosomal recessive disorders. In this group of patients, deletion regions cannot amplify with PCR method and they are detectable with this way, but patients with 
long heterozygous deletions because of having one normal copy of gene are not detectable with PCR-SSCP method and sequencing analysis. So far, there is no report about long deletions related with TPO gene but the probability of existence of these type of mutations should be investigated in studied population in our future studies.

In conclusion, because of low prevalence of TPO gene mutation in this study, it is necessary to investigate more studies with large sample by using another screening method besides SSCP and screening of intronic and regulatory TPO gene mutations and mutation detection of other genes that had effect on thyroid dyshormonogenesis.

\section{Acknowledgments}

This study was funded by the Bureau for Research, Isfahan University of Medical Sciences, and was done in Molecular Medicine Department of Pasteur Institute of Iran. The authors thank all the staff working in Isfahan Endocrine and Metabolic Research Center and Molecular Medicine Department of Pasteur Institute of Iran for their kind cooperation with their research project.

\section{References}

[1] M. V. Rastogi and S. H. LaFranchi, "Congenital hypothyroidism," Orphanet Journal of Rare Diseases, vol. 5, no. 1, article 17, 2010.

[2] A. Grüters and H. Krude, "Update on the management of congenital hypothyroidism," Hormone Research, vol. 68, pp. 107$111,2007$.

[3] S. M. Park and V. K. K. Chatterjee, "Genetics of congenital hypothyroidism,” Journal of Medical Genetics, vol. 42, no. 5, pp. 379-389, 2005.

[4] A. C. Nascimento, D. R. Guedes, C. S. Santos, M. Knobel, I. G. S. Rubio, and G. Medeiros-Neto, "Thyroperoxidase gene mutations in congenital goitrous hypothyroidism with total and partial iodide organification defect," Thyroid, vol. 13, no. 12, pp. 1145-1151, 2003.

[5] S. Kimura, Y. S. Hong, T. Kotani, S. Ohtaki, and F. Kikkawa, "Structure of the human thyroid peroxidase gene: comparison and relationship to the human myeloperoxidase gene," Biochemistry, vol. 28, no. 10, pp. 4481-4489, 1989.

[6] C. Ris-Stalpers and H. Bikker, "Genetics and phenomics of hypothyroidism and goiter due to TPO mutations," Molecular and Cellular Endocrinology, vol. 322, no. 1-2, pp. 38-43, 2010.

[7] C. L. S. Santos, H. Bikker, K. G. M. Rego et al., "A novel mutation in the TPO gene in goitrous hypothyroid patients with iodide organification defect," Clinical Endocrinology, vol. 51, no. 2, pp. 165-172, 1999.

[8] H. Bikker, M. T. Den Hartog, F. Baas, M. H. Gons, T. Vulsma, and J. J. M. De Vijlder, "A 20-basepair duplication in the human thyroid peroxidase gene results in a total iodide organification defect and congenital hypothyroidism," Journal of Clinical Endocrinology and Metabolism, vol. 79, no. 1, pp. 248-252, 1994.

[9] H. Bikker, T. Vulsma, F. Baas, and J. J. M. De Vijlder, "Identification of five novel inactivating mutations in the human thyroid peroxidase gene by denaturing gradient gel electrophoresis," Human Mutation, vol. 6, no. 1, pp. 9-16, 1995.
[10] T. Kotani, K. Umeki, I. Yamamoto, S. Ohtaki, M. Adachi, and K. Tachibana, "Iodide organification defects resulting from cosegregation of mutated and null thyroid peroxidase alleles," Molecular and Cellular Endocrinology, vol. 182, no. 1, pp. 6168, 2001.

[11] S. Pannain, R. E. Weiss, C. E. Jackson et al., "Two different mutations in the thyroid peroxidase gene of a large inbred Amish kindred: power and limits of homozygosity mapping," Journal of Clinical Endocrinology and Metabolism, vol. 84, no. 3, pp. 1061-1071, 1999.

[12] B. Bakker, H. Bikker, T. Vulsma, J. S. E. De Randamie, B. M. Wiedijk, and J. J. M. De Vijlder, "Two decades of screening for congenital hypothyroidism in the Netherlands: TPO gene mutations in total iodide organification defects (an update)," Journal of Clinical Endocrinology and Metabolism, vol. 85, no. 10, pp. 3708-3712, 2000.

[13] B. Bakker, H. Bikker, R. C. M. Hennekam et al., "Maternal isodisomy for chromosome $2 \mathrm{p}$ causing severe congenital hypothyroidism," Journal of Clinical Endocrinology and Metabolism, vol. 86, no. 3, pp. 1164-1168, 2001.

[14] K. Umeki, T. Kotani, J. I. Kawano et al., "Two novel missense mutations in the thyroid peroxidase gene, R665W and G771R, result in a localization defect and cause congenital hypothyroidism," European Journal of Endocrinology, vol. 146, no. 4, pp. 491-498, 2002.

[15] D. M. Niu, B. Hwang, Y. K. Chu, C. J. Liao, P. L. Wang, and C. Y. Lin, "High prevalence of a novel mutation (2268 insT) of the thyroid peroxidase gene in Taiwanese patients with total iodide organification defect, and evidence for a founder effect," Journal of Clinical Endocrinology and Metabolism, vol. 87, no. 9, pp. 4208-4212, 2002.

[16] J. Y. Wu, S. G. Shu, C. F. Yang, C. C. Lee, and F. J. Tsai, "Mutation analysis of thyroid peroxidase gene in Chinese patients with total iodide organification defect: identification of five novel mutations," Journal of Endocrinology, vol. 172, no. 3, pp. 627-635, 2002.

[17] K. Umeki, T. Kotani, J. I. Kawano et al., "Two novel missense mutations in the thyroid peroxidase gene, R665W and G771R, result in a localization defect and cause congenital hypothyroidism," European Journal of Endocrinology, vol. 146, no. 4, pp. 491-498, 2002.

[18] C. M. Rivolta, S. A. Esperante, L. Gruñeiro-Papendieck et al., "Five novel inactivating mutations in the thyroid peroxidase gene responsible for congenital goiter and iodide organification defect," Human Mutation, vol. 22, no. 3, p. 259, 2003.

[19] C. Rodrigues, P. Jorge, J. Pires Soares et al., "Mutation screening of the thyroid peroxidase gene in a cohort of 55 Portuguese patients with congenital hypothyroidism," European Journal of Endocrinology, vol. 152, no. 2, pp. 193-198, 2005.

[20] P. Ambrugger, I. Stoeva, H. Biebermann, T. Torresani, C. Leitner, and A. Grüters, "Novel mutations of the thyroid peroxidase gene in patients with permanent congenital hypothyroidism," European Journal of Endocrinology, vol. 145, no. 1, pp. 19-24, 2001.

[21] T. Tajima, J. Tsubaki, and K. Fujieda, "Two novel mutations in the thyroid peroxidase gene with goitrous hypothyroidism," Endocrine Journal, vol. 52, no. 5, pp. 643-645, 2005.

[22] N. Pfarr, T. J. Musholt, P. B. Musholt, R. Brzezinska, and J. Pohlenz, "Congenital primary hypothyroidism with subsequent adenomatous goiter in a Turkish patient caused by a homozygous 10-bp deletion in the thyroid peroxidase (TPO) gene," Clinical Endocrinology, vol. 64, no. 5, pp. 514-518, 2006. 
[23] N. Pfarr, G. Borck, A. Turk et al., "Goitrous congenital hypothyroidism and hearing impairment associated with mutations in the TPO and SLC26A4/PDS genes," Journal of Clinical Endocrinology and Metabolism, vol. 91, no. 7, pp. 2678-2681, 2006.

[24] Y. Tenenbaum-Rakover, S. Mamanasiri, C. Ris-Stalpers et al., "Clinical and genetic characteristics of congenital hypothyroidism due to mutations in the thyroid peroxidase (TPO) gene in Israelis," Clinical Endocrinology, vol. 66, no. 5, pp. 695$702,2007$.

[25] M. Hashemipour, M. Amini, R. Iranpour et al., "Prevalence of congenital hypothyroidism in Isfahan, Iran: results of a survey on 20,000 neonates," Hormone Research, vol. 62, no. 2, pp. 7983, 2004.

[26] F. Delange, "Screening for congenital hypothyroidism used as an indicator of the degree of iodine deficiency and of its control," Thyroid, vol. 8, no. 12, pp. 1185-1192, 1998.

[27] M. Hashemipoor, M. Amini, A. Gheisari, S. Sharifei, R. Iranpour, and A. Aminorroaya, "Comparison of urinary iodine excretion in neonates and their mothers in Isfahan, Iran," Endocrine Practice, vol. 8, no. 5, pp. 347-350, 2002.

[28] M. Hashemipour, S. Hovsepian, R. Kelishadi et al., "Permanent and transient congenital hypothyroidism in IsfahanIran," Journal of Medical Screening, vol. 16, no. 1, pp. 11-16, 2009.

[29] M. Hashemipour, M. Amini, M. Talaie et al., "Parental consanguinity among parents of neonates with congenital hypothyroidism in Isfahan," Eastern Mediterranean Health Journal, vol. 13, no. 3, pp. 567-574, 2007.

[30] R. Iranpour, M. Hashemipour, M. Amini et al., "[Tc]-99m thyroid scintigraphy in congenital hypothyroidism screening program," Journal of Tropical Pediatrics, vol. 52, no. 6, pp. 411415, 2006.

[31] S. A. Miller, D. D. Dykes, and H. F. Polesky, "A simple salting out procedure for extracting DNA from human nucleated cells," Nucleic Acids Research, vol. 16, no. 3, p. 1215, 1988.

[32] S. C. Neves, P. R. Mezalira, V. M. A. Dias et al., "Monoallelic thyroid peroxidase gene mutation in a patient with congenital hypothyroidism with total iodide organification defect," Arquivos Brasileiros de Endocrinologia e Metabologia, vol. 54, no. 8, pp. 732-737, 2010.

[33] S. Narumi, K. Muroya, Y. Asakura, M. Aachi, and T. Hasegawa, "Molecular basis of thyroid dyshormonogenesis: genetic screening in population-based Japanese patients," Journal of Clinical Endocrinology and Metabolism, vol. 96, no. 11, pp. E1838-E1842, 2011.

[34] A. C. Nascimento, D. R. Guedes, C. S. Santos, M. Knobel, I. G. S. Rubio, and G. Medeiros-Neto, "Thyroperoxidase gene mutations in congenital goitrous hypothyroidism with total and partial iodide organification defect," Thyroid, vol. 13, no. 12, pp. 1145-1151, 2003.

[35] J. C. Moreno, H. Bikker, M. J. E. Kempers et al., "Inactivating mutations in the gene for thyroid oxidase 2 (THOX2) and congenital hypothyroidism," New England Journal of Medicine, vol. 347, no. 2, pp. 95-102, 2002.

[36] M. Orita, H. Iwahana, H. Kanazawa, K. Hayashi, and T. Sekiya, "Detection of polymorphisms of human DNA by gel electrophoresis as single-strand conformation polymorphisms," Proceedings of the National Academy of Sciences of the United States of America, vol. 86, no. 8, pp. 2766-2770, 1989.

[37] K. Hayashi, "PCR-SSCP: a simple and sensitive method for detection of mutations in the genomic DNA," PCR methods and applications, vol. 1, no. 1, pp. 34-38, 1991.
[38] P. Nollau and C. Wagener, "Methods for detection of point mutations: performance and quality assessment. The IFCC Scientific Division, Committee on Molecular Biology Techniques," Journal of the International Federation of Clinical Chemistry, vol. 9, no. 4, pp. 162-170, 1997. 


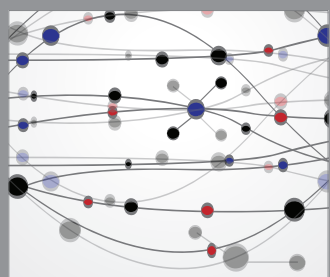

The Scientific World Journal
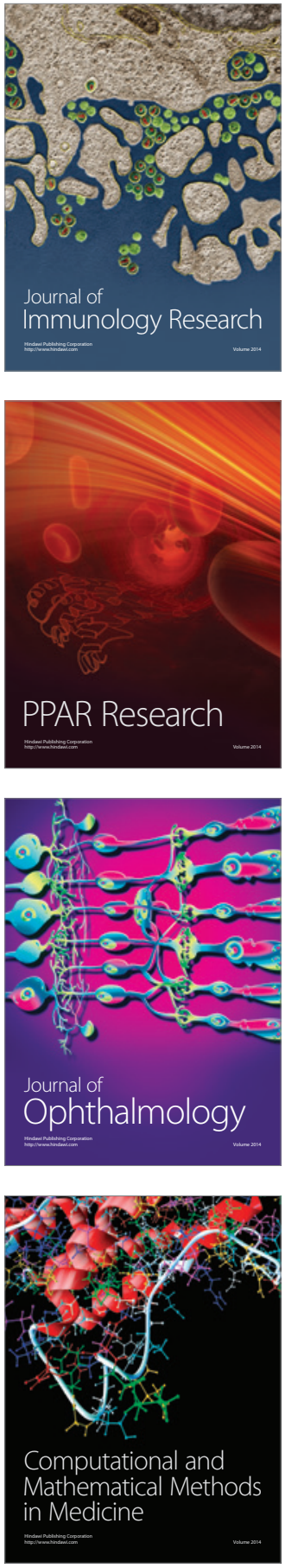

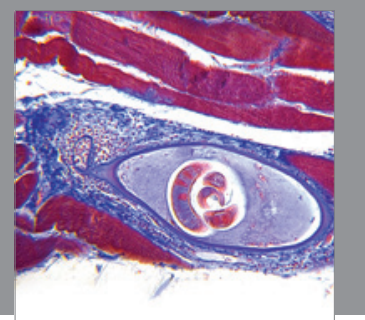

Gastroenterology

Research and Practice
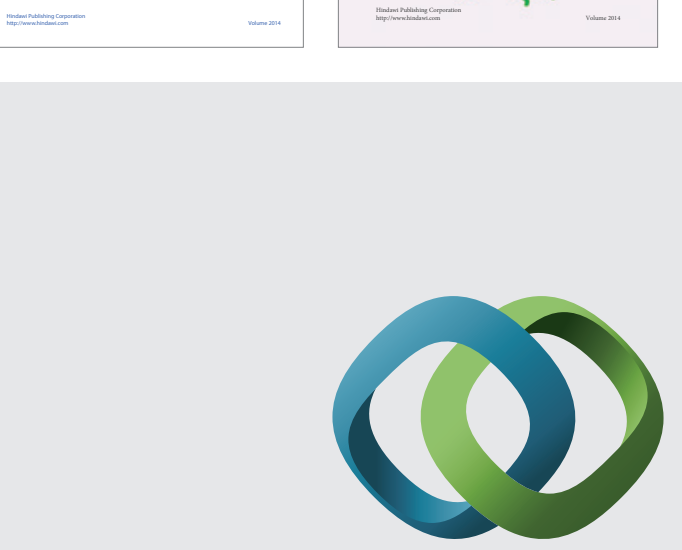

\section{Hindawi}

Submit your manuscripts at

http://www.hindawi.com
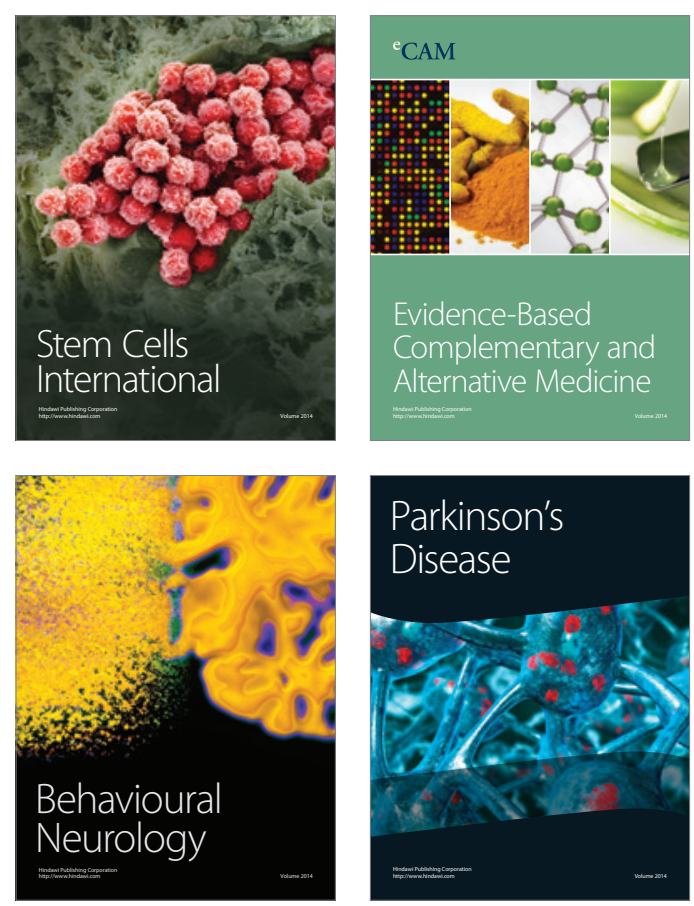

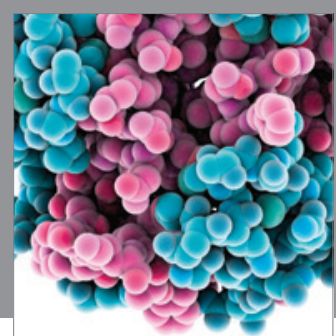

Journal of
Diabetes Research

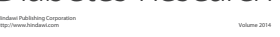

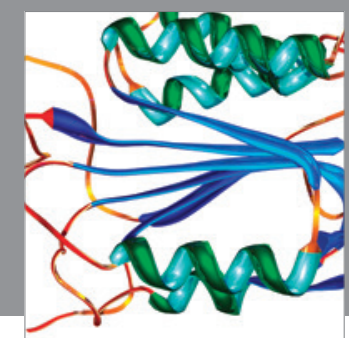

Disease Markers
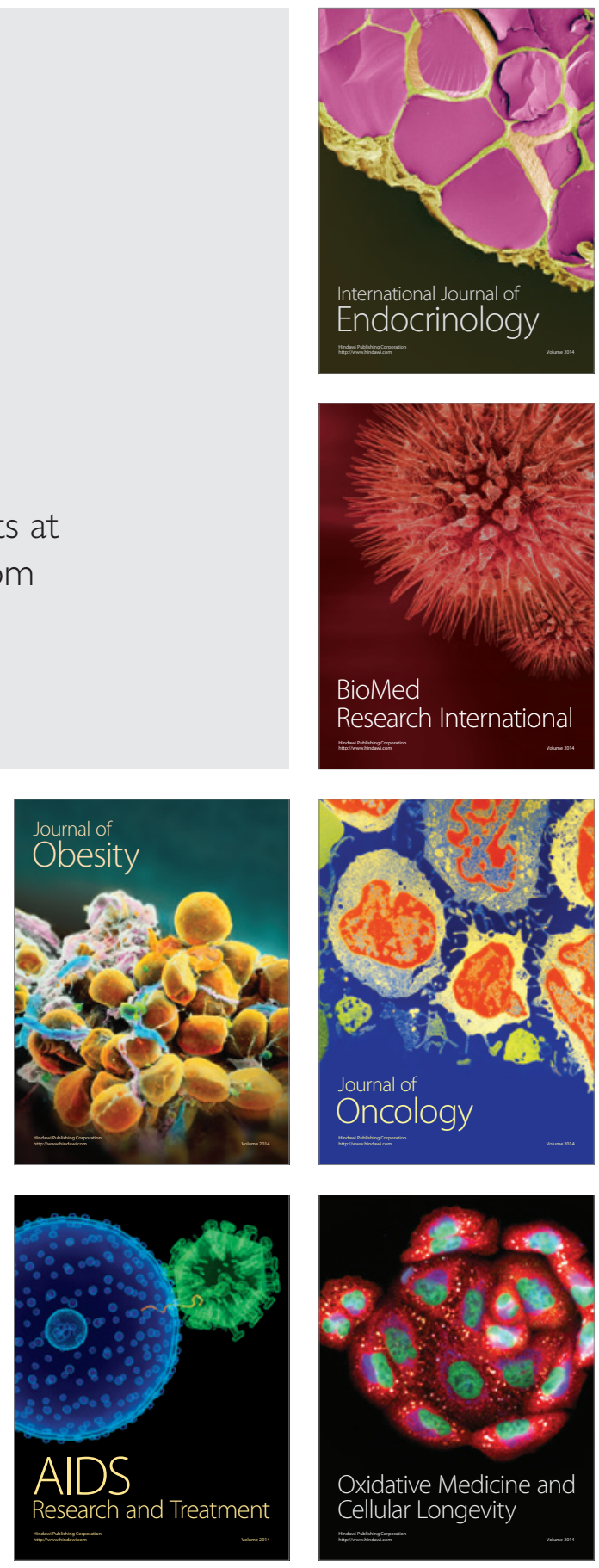